\title{
Geological and geomorphological controls on groundwater occurrence in a hard rock region
}

\author{
S. P. Rajaveni ${ }^{1} \cdot$ K. Brindha $^{2} \cdot$ L. Elango ${ }^{1}$
}

Received: 14 December 2014/ Accepted: 25 August 2015/Published online: 5 September 2015

(C) The Author(s) 2015. This article is published with open access at Springerlink.com

\begin{abstract}
Remote sensing and GIS tools have broadly helped hydrogeologists to delineate the groundwater prospective zones for watershed development and management. The origin, movement and existence of groundwater depends on several factors such as slope, drainage density, land use, geology, lineament density and geomorphology. Based on these, the mapping and identification of groundwater potential zones were carried out in a part of Nalgonda district, Telangana, India. The regions were categorised as high, moderate and low groundwater potential, and they were validated with the groundwater levels and yield of wells located in the corresponding zones. Extensive possibility for watershed development is possible in $41 \%$ of the total $724 \mathrm{~km}^{2}$ and $46 \%$ of the area offers moderate options. Any groundwater management project implemented in these favourable areas will bring maximum benefit. Similar studies should be considered necessary before designing a water resource development activity as it will reduce the cost on detailed field visits which are time-consuming.
\end{abstract}

Keywords Groundwater potential zones - Overlay analysis $\cdot$ Thematic layers $\cdot$ Nalgonda $\cdot$ Telangana $\cdot$ India

L. Elango

elango34@hotmail.com; elango@annauniv.edu

1 Department of Geology, Anna University, Chennai 600025 , India

2 International Water Management Institute, Vientiane, Lao PDR

\section{Introduction}

In a semi-arid country like India, surface water is not available throughout the year for various purposes. Due to meagre surface water resource, most of the requirements for irrigation, industry and domestic purposes are being met from groundwater. It is therefore essential to ensure the availability of groundwater throughout the year. Of many methods available, remote sensing is one of the techniques that can be used for rapid assessment of natural resources; however, it requires validation by field work. With the advances and availability of satellite images, it is possible to indirectly identify the ground conditions through the surface and subsurface features such as topography, land use, drainage, geology and geomorphology.

Remote sensing and geographic information system (GIS) have proved to be important tools to prepare the thematic maps from satellite images and is also used as a multi-criteria decision analysis tool (Vittala et al. 2005; Madrucci et al. 2008; Mondal et al. 2008; Javed and Wani 2009; Jha et al. 2010; Dar et al. 2010). Application of remote sensing and GIS in geology and geomorphology for quick hydrogeological evaluation has been proved to be efficient (Pareta and Pareta 2011; Suganthi et al. 2013; Anbazhagan and Jothibasu 2014; Ndatuwong and Yadav 2014). Interpretation of various features has also been done by visual method, which is time-consuming and difficult in areas where accessibility is not possible to humans. To overcome these constraints, integrating remote sensing and GIS methods gives more accuracy and reduces the risk of manual error (Pinder 2002; Prasad et al. 2008; Dar et al. 2011; Jasmin and Mallikarjuna 2011). Another advantage is that both discrete and continuous data from primary and secondary sources can be combined and interpreted by this method (Burrough 1986). Rai et al. (2005), Karunanidhi 
et al. (2013), Rashid et al. (2012) and Srinivasan et al. (2013) complemented remote sensing methods with geoelectrical studies to identify the groundwater prospective zones. Researchers have also used statistical methods (Ozdemir 2011; Machiwal et al. 2011; Manap et al. 2012, 2013; Pinto et al. 2015) and numerical modelling (Chenini and Mammou 2010; Gaur et al. 2011; Ahmad et al. 2011) along with GIS for groundwater potential mapping. Ideally, GIS is a rapid and cost-effective problem-solving platform for identifying groundwater potential zones. If this method is complemented with necessary ground checks, it will be an effective technique in hydrogeological studies. This has been agreed broadly in groundwater assessment studies, and several researchers have identified the groundwater potential zones in various regions by the integration of remote sensing and GIS (Sener et al. 2005; Varughese et al. 2012; Lone et al. 2013; Narendra et al. 2013)

Nalgonda district in Telangana, southern India, is intensively irrigated, and groundwater $(57.2 \%)$ is the major source of supply for agriculture (CGWB 2007). The groundwater quality of this area has been studied earlier (Brindha and Elango 2013a, b; Brindha and Elango 2012; Elango et al. 2012; Rajesh et al. 2012; Brindha et al. 2011; Brindha and Elango 2010). In spite of the large-scale use of groundwater in this area, it has not been classified based on groundwater potential and a study of this nature is essential to sustainably utilise the available groundwater resources and to meet the growing needs for agricultural, domestic and industrial activities. Hence, this study was carried out with an objective to map the groundwater potential zones in a part of Nalgonda district with the help of thematic maps prepared using remote sensing and GIS. The results of this study were validated using the groundwater level monitored in these areas.

\section{Data collection}

Toposheet was used as a reference for preparing the thematic maps. Survey of India toposheets $(1: 25,000)$ covering the study area was used to prepare the base map, drainage and topographical maps. Geological map of Geological Survey of India (GSI), Hyderabad, was used to identify the different geological features of this area (GSI 1995). This was further updated by ground-truth verification carried out by geological fieldwork along different traverses across the area in July 2010. Vertical electrical sounding (VES) was carried out in 37 locations of the study area to understand the geology and also to verify the extent of weathering. Geomorphology and land use of the area were delineated from the Indian Remote Sensing Satellite P6 (Resourcesat-1) Linear Imaging Self-scanning Sensor
IV (IRS P6 LISS IV) images of the year 2008 with a spatial resolution of $5.8 \mathrm{~m}$ by visual interpretation technique. Figure 1 shows the steps adopted for this study. For the verification process, groundwater levels were measured in forty-two monitoring wells in this area once in 2 months from March 2008 to January 2009 using a water level indicator (Solinst 101). Global positioning system (GPS) was used to measure the topographical elevation at the groundwater level measuring location. Further five pumping tests were also carried out to determine the yield of wells to validate the groundwater potential zones.

\section{Description of the study area}

The study area (Fig. 2) $\left(724 \mathrm{~km}^{2}\right)$ is located in Nalgonda district, Telangana, India. This area is situated at a distance of about $80 \mathrm{~km}$ ESE of Hyderabad, the capital of Telangana state. Nagarjuna Sagar reservoir is present at the south-eastern side of the study area. The southern boundary is bounded by Pedda Vagu River and the northern boundary is partly bounded by Gudipalli Vagu River. The climate in this area is arid to semi-arid. The temperature ranges from 30 to $46.5{ }^{\circ} \mathrm{C}$ during summer (April-June) and between 17 and $38{ }^{\circ} \mathrm{C}$ during winter (November-January). South-west monsoon occurs during June-September resulting in an average annual rainfall of about $600 \mathrm{~mm}$.

\section{Results and discussions}

The quality of a study of this nature will improve depending on the number of accurate thematic layers that have been used. Depending on the availability of data and resources, this study is limited to and concentrates on the use of slope, drainage density, land use, geology, lineament density and geomorphological characteristics. Table 1 gives the area covered by various features of a spatial layer, and Table 2 gives the ranks and weights assigned to the features based on literature.

\section{Slope}

The influence of slope will have a remarkable effect on the infiltration of surface water from the ground. A low slope percentage indicates that the surface water received mainly because of precipitation will have more time to remain on the ground surface and percolate into the subsurface. In case of highly sloping areas, the run-off is more immediate offering less retention time for the water on the ground surface and significantly reduces the groundwater recharge potential. As the slope greatly depends on the elevation in an area, to determine this characteristic, the topography should be known. 
Fig. 1 Methodology adopted for identification of groundwater potential zones
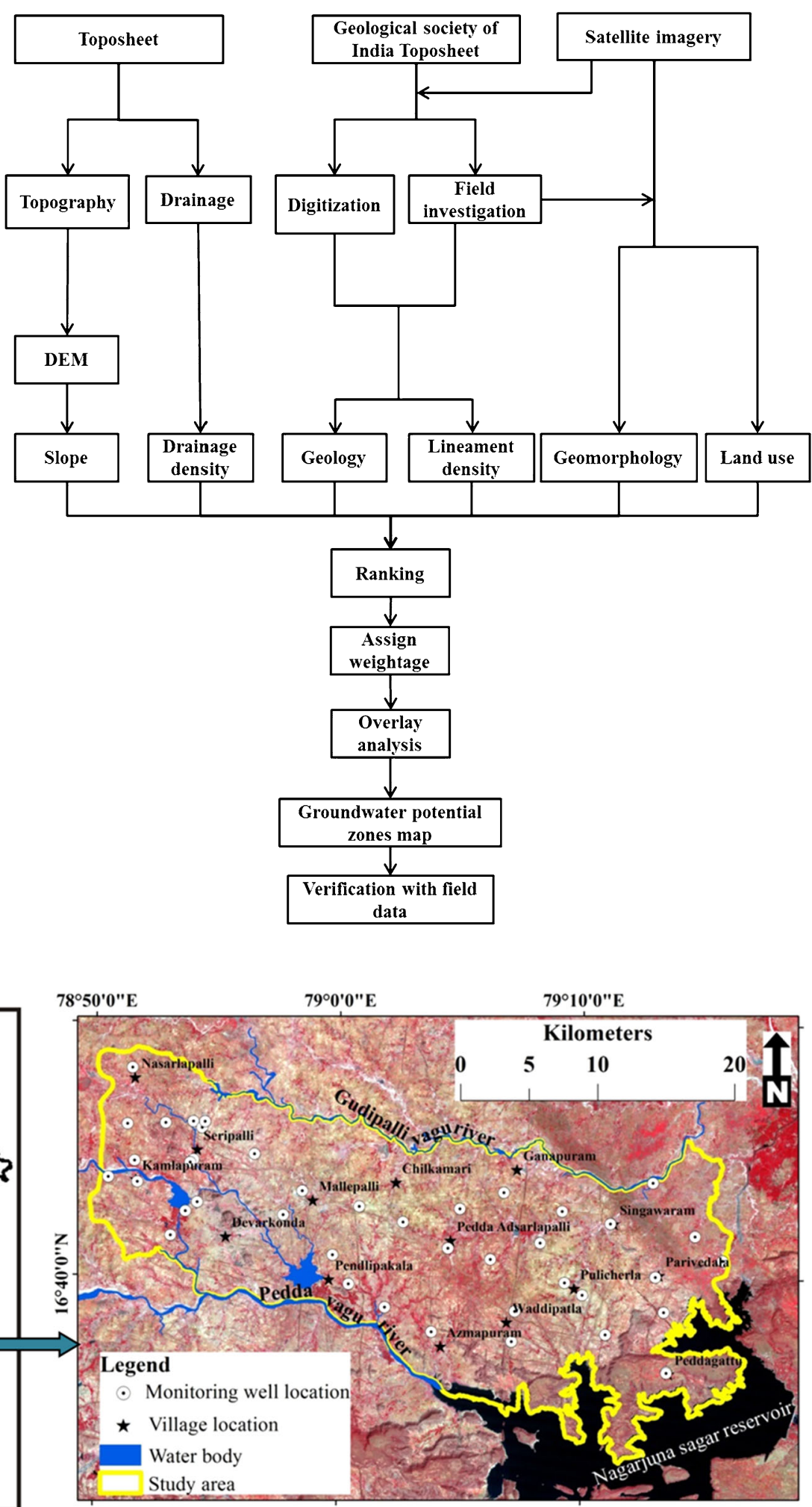

Fig. 2 Location of the study area

Topography of the study area delineated from the toposheets $(1: 25,000$ scale) comprises of three distinct features. The Nagarjuna Sagar reservoir in the south- eastern hemicircle, the Lambapur-Peddagattu and Seripalli plateaus and the gently sloping undulating land make up the varied topographical characteristics of this area. The 
Table 1 Area covered under different range of parameters

\begin{tabular}{|c|c|c|c|}
\hline Parameter & Range & $\begin{array}{l}\text { Area in } \\
\mathrm{km}^{2}\end{array}$ & Percentage \\
\hline \multirow[t]{3}{*}{ Slope } & $1^{\circ}-5^{\circ}$ & 674.5 & 93.2 \\
\hline & $5^{\circ}-20^{\circ}$ & 33.9 & 4.7 \\
\hline & $20^{\circ}-80^{\circ}$ & 15.6 & 2.2 \\
\hline \multirow[t]{5}{*}{ Land use } & Water body & 57.5 & 7.9 \\
\hline & Waste land & 140.3 & 19.4 \\
\hline & Forest & 56.5 & 7.8 \\
\hline & Built-up & 18.5 & 2.6 \\
\hline & Agriculture & 451.2 & 62.3 \\
\hline \multirow[t]{8}{*}{ Geomorphology } & Denudational hill & 36.6 & 5.1 \\
\hline & Linear ridge & 7.7 & 1.1 \\
\hline & Pediments & 39.5 & 5.5 \\
\hline & Pediplain & 560.4 & 77.4 \\
\hline & Water body & 11.1 & 1.5 \\
\hline & Residual hill & 10.1 & 1.4 \\
\hline & Structural hill & 48.1 & 6.6 \\
\hline & Valley fill & 10.7 & 1.5 \\
\hline \multirow[t]{10}{*}{ Geology } & Quartzite & 22.8 & 3.2 \\
\hline & Quartz vein & 1.5 & 0.2 \\
\hline & Pink biotite granite & 36.4 & 5.0 \\
\hline & Migmatite granite & 75.4 & 10.4 \\
\hline & Meta-basalt & 10.2 & 1.4 \\
\hline & Meta-rhyolite & 0.6 & 0.1 \\
\hline & Grey biotite granite & 557.4 & 77.0 \\
\hline & $\begin{array}{l}\text { Grey hornblende } \\
\text { biotite }\end{array}$ & 10.5 & 1.5 \\
\hline & Grey biotite gneiss & 7.2 & 1.0 \\
\hline & Dolerite & 2.0 & 0.3 \\
\hline \multirow{3}{*}{$\begin{array}{l}\text { Drainage density } \\
\left(\mathrm{km}^{-1}\right)\end{array}$} & $0-0.75$ & 243.4 & 33.6 \\
\hline & $0.75-2.39$ & 345.8 & 47.8 \\
\hline & $2.39-5.08$ & 134.9 & 18.6 \\
\hline \multirow{3}{*}{$\begin{array}{l}\text { Lineament density } \\
\left(\mathrm{km}^{-1}\right)\end{array}$} & $0-0.37$ & 468.7 & 64.7 \\
\hline & $0.37-1.08$ & 175.6 & 24.3 \\
\hline & $1.08-2.96$ & 79.7 & 11.0 \\
\hline
\end{tabular}

extreme south-east occupied by the Nagarjuna Sagar reservoir has maximum water level at 180 mamsl. There are several small hills in this area with height ranging from 250 to 300 mamsl. The Lambapur and Peddagattu plateaus occur as flat topped hills in the south-east of the study area. The highest topographical elevation of this area is 348.1 mamsl and lowest is 169.5 mamsl. The ground surface generally slopes towards the south-east direction. DEM was generated from $10-\mathrm{m}$ interval contour of the topographical map, which is given in Fig. 3a. Slope varied from $1^{\circ}$ to $80^{\circ}$ (Fig. 3b), and most parts of the area have slope ranging from $1^{\circ}$ to $2.5^{\circ}$ (Table 1 ). The south-east and north-west regions of the study area have a slope ranging from $2.5^{\circ}$ to $80^{\circ}$. For the assessment of groundwater potential zones, this area was classified based on three ranges of slope (Fig. 3b). The range with lesser slope $\left(0^{\circ}\right.$ $5^{\circ}$ ) was given a higher rank of 4 as it increases the infiltration rate (Lone et al. 2013), whereas a higher slope from $20^{\circ}$ to $80^{\circ}$ was given a low rank of 1 (Bagyaraj et al. 2013).

\section{Land use}

The dependence on groundwater especially quantitatively is determined by the land use in an area. Figure 4 shows that the land use in this area which comprises of agricultural land (cropland, fallow land and plantation), water bodies (stream and tank), forest plantation, wasteland (land with or without scrub, stony waste, rocky knob and sheet rock area) and built-up area as identified from LISS IV imagery. Area occupied by different land-use characteristics is given in Table 1. Irrigation is mainly (57\%) dependent on groundwater (CGWB 2007) apart from rainfall. The cropping pattern depends on the climatic conditions and availability of water sources. Paddy, sweet lime, castor, cotton, grams and groundnut are the major crops grown in this area. Majority of the livelihood is from agriculture and its allied activities.

The demarcation of different land use in the study area was derived from false colour composite (FCC) IRS LISS IV images by visual interpretation techniques (Fig. 4). The crop land was identified by light medium red tone and fine/ medium texture; fallow land was identified by medium burly wood tone and medium texture; plantation was identified by dark red tone and fine texture, respectively (Lone et al. 2013). These are classified as good potential sites for groundwater prospects (Varughese et al. 2012). Water bodies were displayed in black tone and were assigned as high potential zones with a rank of 3 (Chipman and Lillesand 2007). Forest plantations had light reddish brown tone and fine medium texture with irregular shape and varying size (Kumar et al. 2008). Groundwater potential in forest areas was assigned as poor because even though these areas may have good groundwater recharge, the groundwater is not being extracted from this land (Magesh et al. 2012). Wasteland was identified by light to dark bluish tone with coarse texture, and built-up land was displayed as light bluish white with fine texture of regular shape and size (Lillesand et al. 2007). These areas were also assigned low values of 1 for mapping the groundwater potential zones (Table 2).

\section{Geology}

Geological mapping serves as a basis for the study of groundwater condition in an area. Particular attention is to be paid to the geological units that affect the occurrence, 
Table 2 Ranks and weightages assigned to various thematic maps for delineation of groundwater potential zones

\begin{tabular}{|c|c|c|c|c|}
\hline Thematic layer & Sub-layers/class & $\begin{array}{l}\text { Rank } \\
(\text { high }=4 \\
\text { low }=1 \text { ) }\end{array}$ & $\begin{array}{l}\text { Weightage } \\
\text { of each } \\
\text { layer }\end{array}$ & References \\
\hline \multirow[t]{3}{*}{ Slope } & Low slope $\left(0^{\circ}-5^{\circ}\right)$ & 3 & \multirow[t]{3}{*}{0.1} & \multirow{3}{*}{$\begin{array}{l}\text { Jasmin and Mallikarjuna (2011), Mondal et al. (2008), } \\
\text { Bagyaraj et al. (2013), Lone et al. (2013) and Rashid } \\
\text { et al. (2012) }\end{array}$} \\
\hline & Medium slope $\left(5^{\circ}-20^{\circ}\right)$ & 2 & & \\
\hline & High slope $\left(>20^{\circ}\right)$ & 1 & & \\
\hline \multirow[t]{3}{*}{ Land use } & Waterbody & 3 & \multirow[t]{3}{*}{0.15} & \multirow{3}{*}{$\begin{array}{l}\text { Kumar et al. (2008), Lone et al. (2013), Nagaraju et al. } \\
\text { (2011), Pandian and Kumanan (2013), Varughese et al } \\
\text { (2012), Sener et al. (2005) }\end{array}$} \\
\hline & Agriculture & 2 & & \\
\hline & Wasteland, built-up, forest & 1 & & \\
\hline \multirow[t]{3}{*}{ Geomorphology } & Water body (reservoir) & 3 & \multirow[t]{3}{*}{0.25} & \multirow{3}{*}{$\begin{array}{l}\text { Dar et al. (2010), Kumar et al. (2008), Bagyaraj et al. } \\
\text { (2013), Lone et al. (2013), Pandian and Kumanan } \\
\text { (2013) }\end{array}$} \\
\hline & Valley fill, pediplain & 2 & & \\
\hline & $\begin{array}{l}\text { Pediments, denudational hill, residual } \\
\text { hill, linear ridge and structural hill }\end{array}$ & 1 & & \\
\hline \multirow[t]{3}{*}{ Geology } & Meta-basalt & 3 & \multirow[t]{3}{*}{0.1} & \multirow{3}{*}{$\begin{array}{l}\text { Jasmin and Mallikarjuna (2011), Kumar et al. (2008), } \\
\text { Lone et al. (2013) }\end{array}$} \\
\hline & $\begin{array}{l}\text { Quartz vein, grey hornblende biotite and } \\
\text { grey biotite gneiss }\end{array}$ & 2 & & \\
\hline & $\begin{array}{l}\text { Meta-rhyolite, dolerite dyke, grey biotite } \\
\text { granite, migmatite granite, pink biotite } \\
\text { granite and quartzite }\end{array}$ & 1 & & \\
\hline \multirow{3}{*}{$\begin{array}{l}\text { Drainage } \\
\text { density }\end{array}$} & Low density $\left(0-0.75 \mathrm{~km}^{-1}\right)$ & 3 & \multirow[t]{3}{*}{0.2} & \multirow{3}{*}{$\begin{array}{l}\text { Jasmin and Mallikarjuna (2011), Mondal et al. (2008), } \\
\text { Bagyaraj et al. (2013), Rashid et al. (2012) }\end{array}$} \\
\hline & Moderate density $\left(0.75-2.39 \mathrm{~km}^{-1}\right)$ & 2 & & \\
\hline & High density $\left(2.39-5.08 \mathrm{~km}^{-1}\right)$ & 1 & & \\
\hline \multirow{3}{*}{$\begin{array}{l}\text { Lineament } \\
\text { density }\end{array}$} & Low density $\left(0-0.37 \mathrm{~km}^{-1}\right)$ & 1 & \multirow[t]{3}{*}{0.2} & \multirow{3}{*}{$\begin{array}{l}\text { Jasmin and Mallikarjuna (2011), Dar et al. (2010), } \\
\text { Mondal et al. (2008), Rashid et al. (2012) }\end{array}$} \\
\hline & Moderate density $\left(0.37-1.08 \mathrm{~km}^{-1}\right)$ & 2 & & \\
\hline & High density $\left(1.08-2.96 \mathrm{~km}^{-1}\right)$ & 3 & & \\
\hline
\end{tabular}

movement and quality of groundwater. Initially, geological map of the region was digitised from GSI map (GSI 1995), which was updated by ground-truth verification carried out in the study area in March 2008. Further the IRS LISS IV data were also used to improve the geological map. Subsequently, another field work was carried out in July 2010 to verify and validate the prepared geological map.

The basement of this area is constituted by medium- to coarse-grained granite (Fig. 5), which comprises the Srisailam formation, the youngest member of Cuddapah super group. Grey and pink granites are exposed in most parts of the area. These rocks have less porosity and are classified into low groundwater potential zones with low rank. Migmatite granite occurs at north-eastern side and the south-eastern part is underlain by Srisailam metamorphic formations. Arenaceous and pebbly-gritty quartzite shale with dolomite limestone, intercalated sequence of shale quartzite and massive quartzite sediments are also present in the Srisailam formations. The stratigraphic sequence occurring in the study area is given in Table 3 , and the area occupied by each geologic feature is given in Table 1 . Generally hard rock does not have primary porosity. Secondary porosity in the form of fractures and weathering only allow groundwater occurrence (Vittala et al. 2005). The extent of weathering was identified based on VES which indicated weathering up to a depth of $40 \mathrm{~m}$ from the ground surface. High rank is assigned for meta-basalt rock (Table 2), which has high amount of porosity and good groundwater potential.

\section{Geomorphology}

The geometric features of different landforms are created by the dynamic action of several geological processes such as temperature changes, freezing and thawing, chemical reactions, seismic shaking and moving of wind and water. Denudational hill, linear ridge, pediments, pediplain, water body, residual hill, structural hill and valley fill were identified from IRS P6 LISS IV image through visual interpretation (Fig. 6). The area occupied by different geomorphological features in the study area is given in Table 1.

Erosion and weathering process creates denudational hill and is poor to infiltration of surface water (Ramaiah et al. 2012). Linear ridges are identified as dark brown tone linear structures. Pediment is the gentle sloping surface

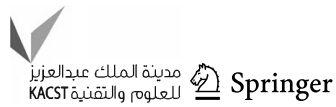


Fig. 3 a Topography (mamsl), b slope characteristics
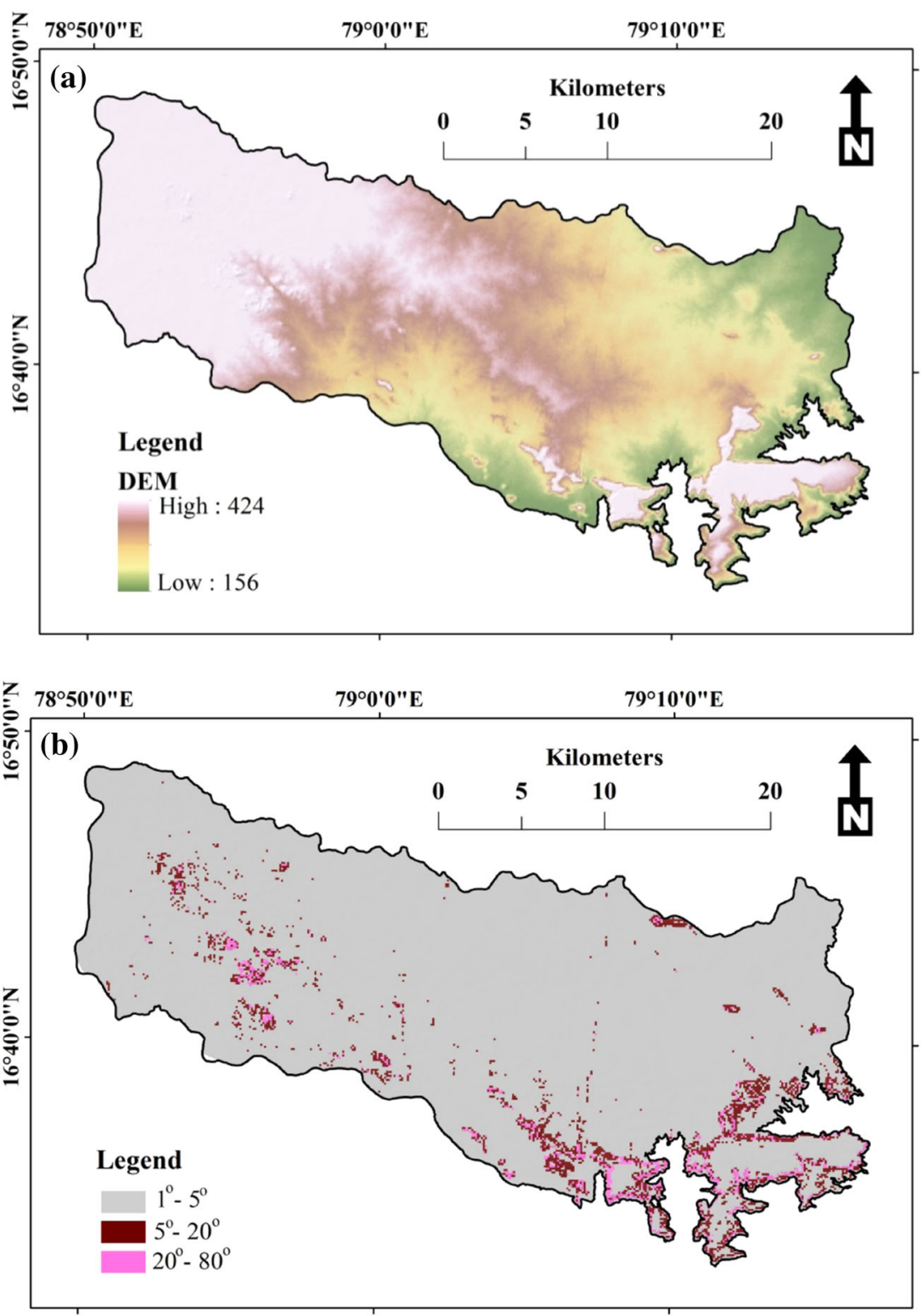

formed between hill and plain surface. These appear as coarse tone and texture in FCC satellite image and have poor groundwater potential. Pediplain appears in light to dark red tone, fine to coarse texture, wide spread size and irregular shape which are associated with agricultural land that yield moderate to good groundwater. In satellite images, residual hill displays brown to dark red tone, coarse texture and large size while structural hill which also appears as brown to dark red tone has coarse texture, small size and are irregular in shape. Valley fill is developed due to the deposition of transported and weathered materials in valley areas that are generally controlled by lineaments. It exhibits dark red to bright red tone on FCC image. Residual hill, structural hill and linear ridge landforms are considered as very low groundwater potential as they are unfractured rock and have low infiltration (Ramaiah et al. 2012). Pediplain, valley fill and water bodies allow high infiltration and have good groundwater potential, hence, are assigned a higher rank (Table 2).

\section{Drainage density}

Drainage in an area depends on the topography, slope and the subsurface characteristics. Drainage density is calculated as the total length of all the streams and rivers in a basin divided by the total area of the drainage basin. The higher the drainage density, the higher the run-off will be, and infiltration of water into the subsurface is affected.

This area is bounded by two major rivers, Pedda Vagu in the south and partly by Gudipalli Vagu in the north. These 
Fig. 4 Land use

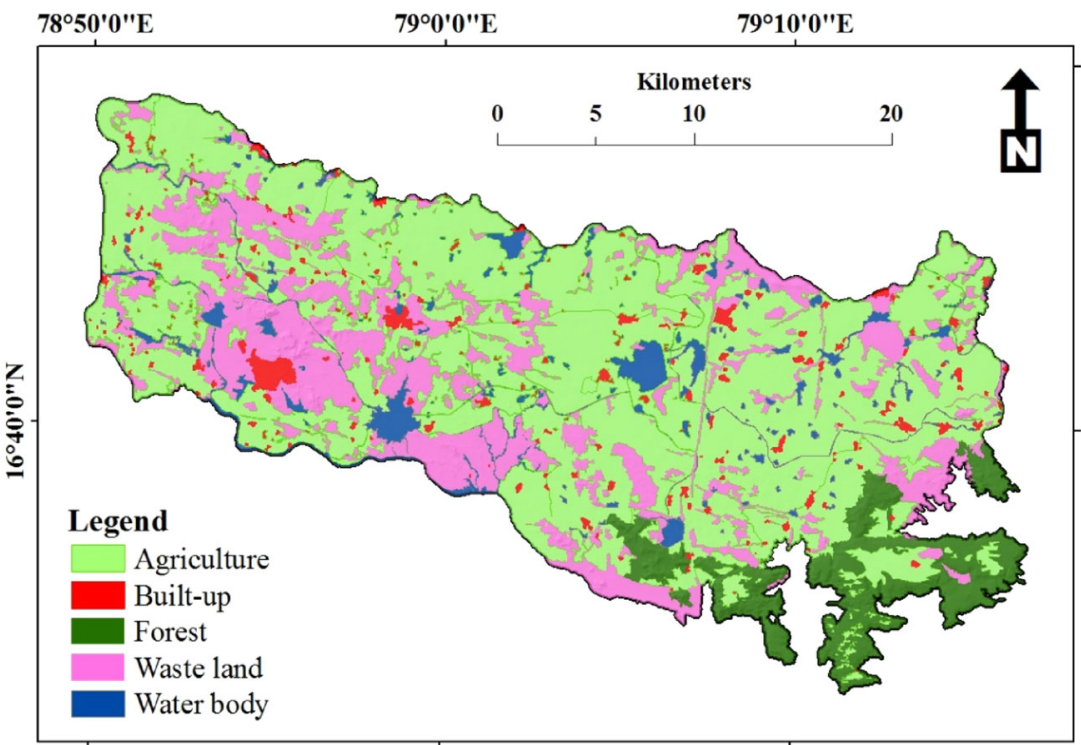

Fig. 5 Geology

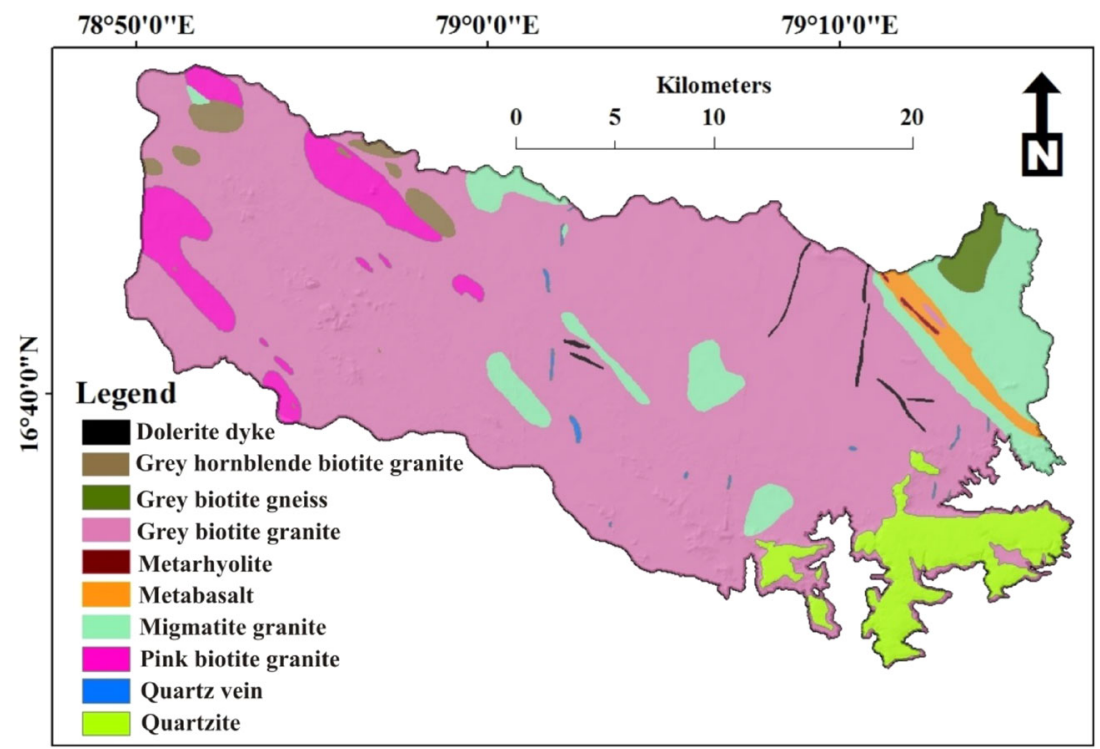

Table 3 Stratigraphic sequence of the study area (after GSI 1995) Cuddapah Super Group Srisailam Formation Massive quartzite Upper shale

Quartzite with shale intercalation

Lower shale with limestone intercalation Pebbly and gritty quartzite/ arenite Unconformity- Uranium mineralized region Granite/ granitic gneiss with intrusion of dolerite dykes and quartz veins two rivers are seasonal and flow during the south-west monsoon falling mainly between July and September. Drainage pattern is mainly dendritic to sub-dendritic (Fig. 7a), whereas trellis-type drainage pattern is also seen in some parts of the area. Many tanks and few small reservoirs are present in the depressed parts of the undulating topography. This area also has wide-lined canal networks catering for irrigation purposes. Drainage density calculated by Kernel density method to understand the potential of the watershed to favour the groundwater potential is given in Fig. 7b. Most of the area falls under 
Fig. 6 Geomorphology

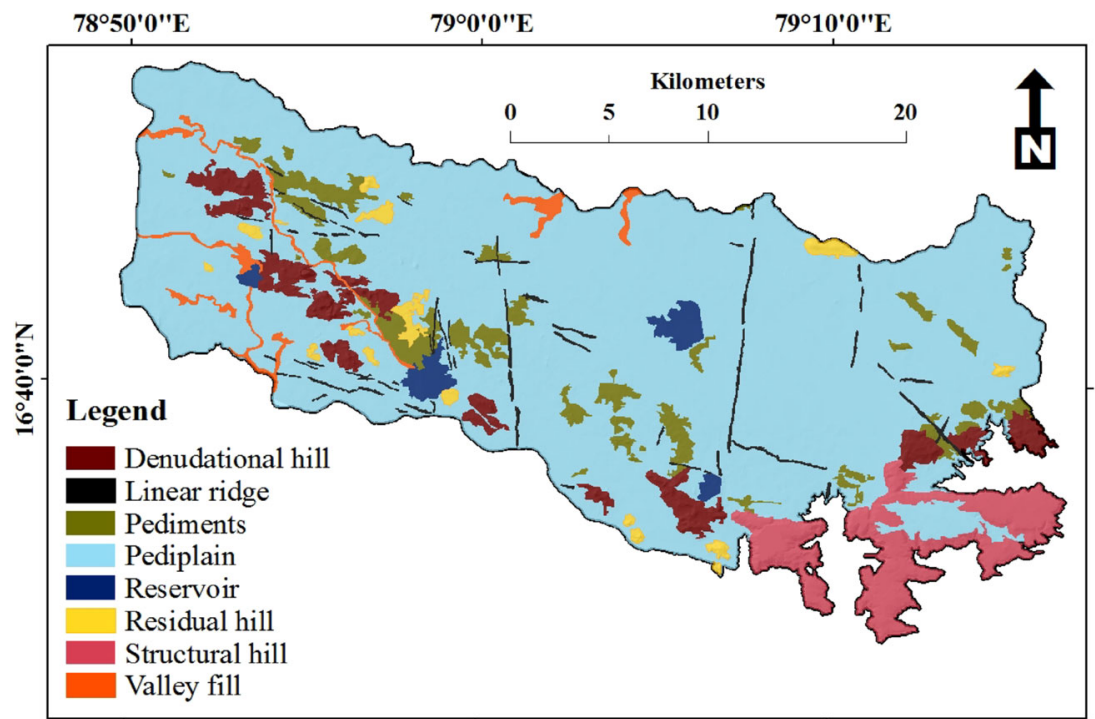

0.75 to $2.39 \mathrm{~km}^{-1}$ drainage density (Table 1 ). The drainage density map was reclassified with areas having less density $\left(0-0.75 \mathrm{~km}^{-1}\right)$ designated with higher rank (Table 2) as they facilitate recharge (Bagyaraj et al. 2013), and areas with high density $\left(2.39-5.08 \mathrm{~km}^{-1}\right)$ were designated with lower rank (Table 2) as they facilitate less infiltration and recharge (Rashid et al. 2012).

\section{Lineament density}

Developed by the tectonic activity, lineaments reflect a general surface manifestation of underground fractures, with inherent characteristics of porosity and permeability of the underlying materials (Rao 2006). These features serve as the main conduits for movement and storage of groundwater in impermeable rocks worldwide (Preeja et al. 2011) in the form of dykes and faults. They were delineated from geological map, satellite imagery and field visits. Fractures seen on the outcrops, excavations and well sections were studied during the field visits, and most of the fractures are trending NNE-SSW and NS (Rajaveni et al. 2014). There are 217 intrusive dolerite dykes and 5 faults which have been identified and mapped. In general, the length of these dykes ranges from 0.17 to $10.23 \mathrm{~km}$, whereas most of the dykes are of length ranging between 0.1 and $1.5 \mathrm{~km}$. From field investigation, it is observed that all the dykes are vertically dipping.

Lineament density map was prepared by using line density method (Fig. 8). The total area falling in different range of lineament density is given in Table 1 which shows that most parts of the area have low lineament density. Around $90 \%$ of lineaments are dykes in this area which might affect groundwater flow and have low groundwater potential. But these dykes are highly weathered and do not act as barrier for groundwater flow which has also been reported by Rajesh et al. (2012) and Rajaveni et al. (2014). So, low lineament density indicates low infiltration rate, whereas the high lineament density areas indicate high infiltration (Table 2) thus a potential zone for groundwater development.

\section{Groundwater potential zonation and validation}

Though several features are used to identify the groundwater prospects, this study limits itself to five features to evaluate the groundwater prospects through satellite-based remote sensing and GIS in a hard rock terrain. The various distinct characteristics and sub-features in each of these thematic layers were reclassified by assigning ranks for computational simplicity. Later, each of these thematic layers were assigned suitable weights based on several studies which is given in Table 2. They were then integrated to bring out a groundwater potential index value based on the following formula.

$$
\begin{aligned}
\text { Groundwater potential index }= & \left(S_{\mathrm{w}} \times S_{\mathrm{r}}\right)+\left(\mathrm{DD}_{\mathrm{w}} \times \mathrm{DD}_{\mathrm{r}}\right) \\
& +\left(\mathrm{LU}_{\mathrm{w}} \times \mathrm{LU}_{\mathrm{r}}\right)+\left(G_{\mathrm{w}}\right. \\
& \left.\times G_{\mathrm{r}}\right)+\left(\mathrm{LD}_{\mathrm{w}} \times \mathrm{LD}_{\mathrm{r}}\right) \\
& +\left(\mathrm{GM}_{\mathrm{w}} \times \mathrm{GM}_{\mathrm{r}}\right)
\end{aligned}
$$

where $S=$ slope; $\mathrm{DD}=$ drainage density; $\mathrm{LU}=$ land use; $G=$ geology $; \mathrm{LD}=$ lineament density; $\mathrm{GM}=$ geomorphology; $w=$ feature weight; $r=$ ranking.

The final map (Fig. 9) prepared using the analysis tool brought out a range of value from 1 to 2.8 . This was further classified into three categories as low (1-1.45), moderate (1.5-1.85) and high (1.9-2.8). About $41.3 \%\left(299 \mathrm{~km}^{2}\right)$ of the area is classified as high groundwater potential, while some parts in the south-east of the study area have low 
Fig. 7 a Drainage and b drainage density
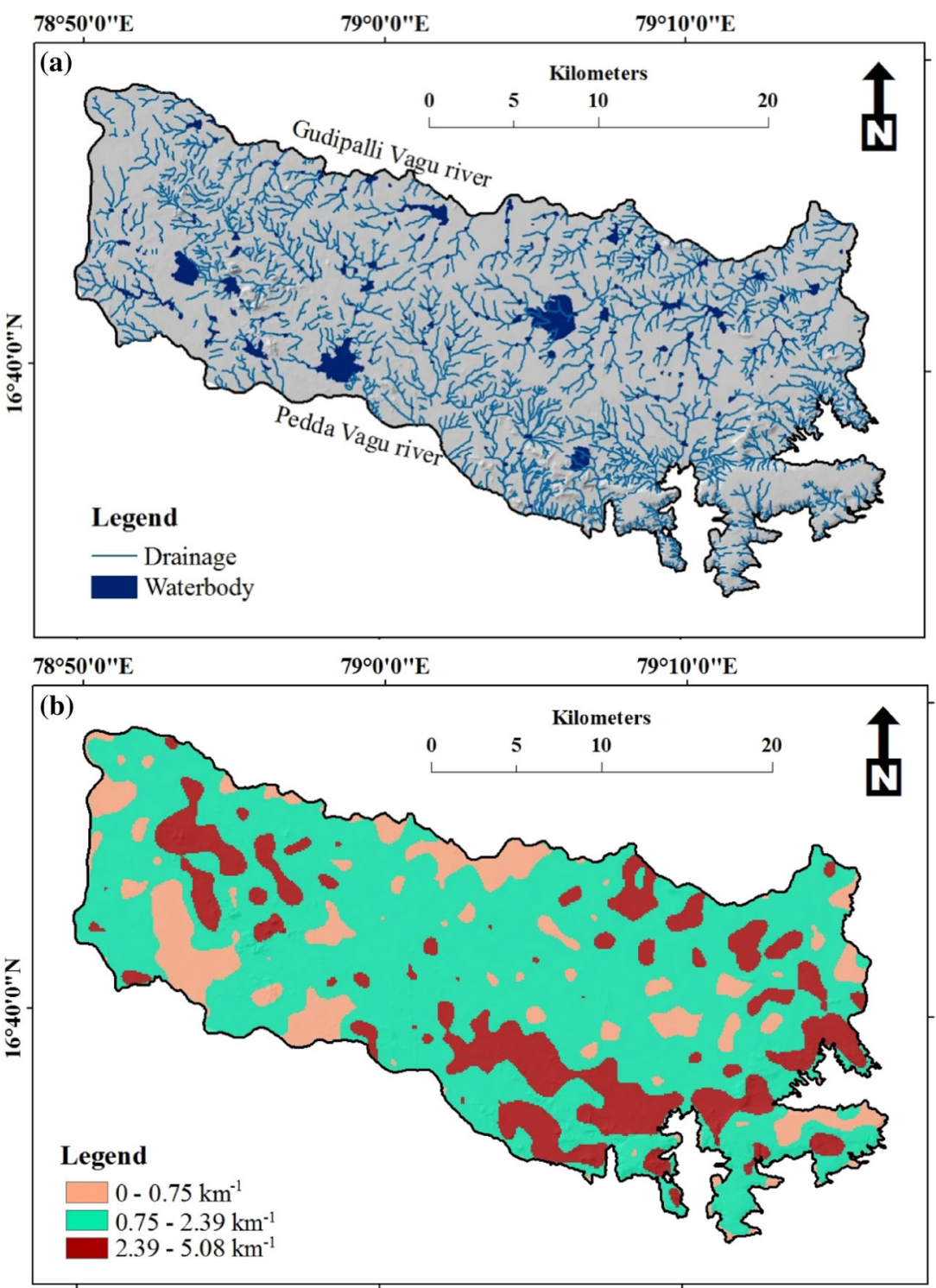

groundwater prospects $(12.5 \%)$. Moderately suitable area for groundwater development was distributed throughout this region occupying $334 \mathrm{~km}^{2}$ of the area (46.1\%).

High groundwater potential areas are present in the agricultural areas with low slope and less drainage density. Lineaments in this area do not affect groundwater potential and high groundwater potential zones occur surrounding high lineament density areas. Groundwater in this area is restricted to geomorphological features of pediplains, valley and pediments. Regions with low groundwater potential area are spread mainly in regions with quartzite and dolerite dyke and with hydrogeomorphological units such as denudational hill, linear ridge, residual hill and structural hill. In general, low slope, low drainage density, low lineament density associated with gneiss are highly promising area for groundwater development. The complex geology, geomorphology and land use result in varied groundwater potential zones of this area. A general observance of the prospective zones based on the various features is given in Table 4.

Groundwater potential zonation map prepared was validated with the groundwater levels measured. Groundwater levels in 42 wells which were more or less uniformly distributed over this area were measured once in 2 months as a part of this study between March 2008 and January 2009. Measurement of groundwater level fluctuation was used to determine the range of variation during the study period. It is observed that the groundwater level fluctuation is comparatively less in the monitoring wells located in zones that are classified as high groundwater potential (Fig. 10). In contrast, in the wells that are located in moderate groundwater potential zones the fluctuation in 
Fig. 8 Lineament density

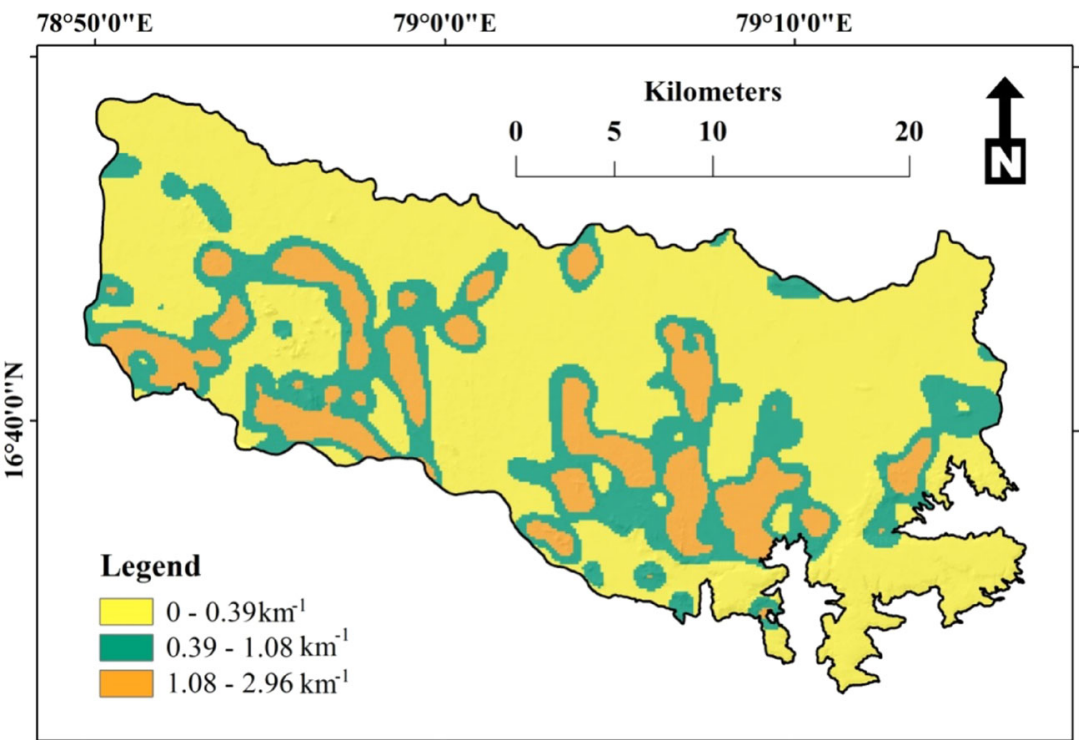

Fig. 9 Groundwater potential zones in a part of Nalgonda district, Telangana, with yield of wells

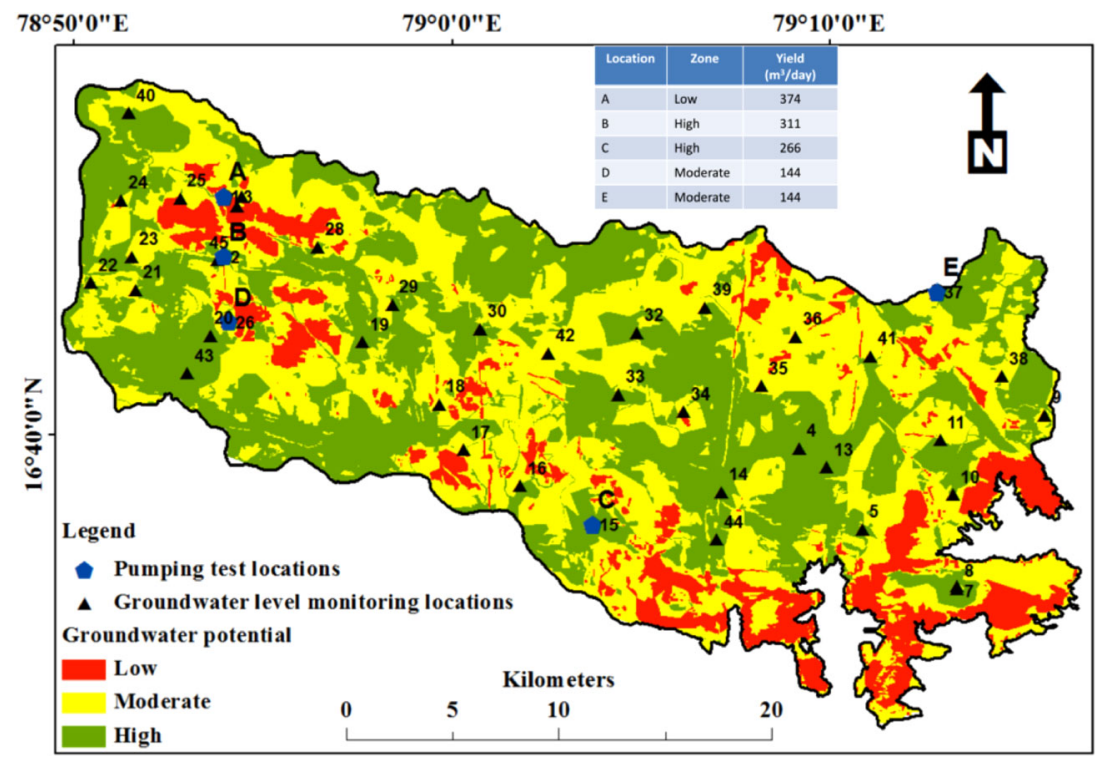

groundwater level was high. In three wells located in the low potential zones, moderate groundwater level fluctuation was observed. However, there are a few exceptions in certain cases which may be due to localised variation in hydrogeological conditions and pattern of groundwater pumping from these wells. Yield of the wells assessed based on pumping tests is shown in Fig. 9 along with groundwater potential zones. Three of the wells were located in high potential zone and two in moderate potential zone, and the yield was higher in the former compared to the latter (Fig. 9). However, the pumping test carried out in well ' $A$ ' located in low groundwater potential zone indicated a high well yield of value $374 \mathrm{~m}^{3} /$ day. This may be due to the possible presence of well intersecting connected fractures. Thus, except for this location there was reasonable comparison between the well yield and the zones of groundwater potential. These analyses confirm that groundwater potential zone map derived by remote sensing and GIS method is reliable for this region. The findings from this study prove to be useful and can be used for groundwater development and governance activities in this area. However, as indicated by a few exceptions in comparison of groundwater level fluctuation and well yield with potential zones, greater care need to be used on the application of remote sensing techniques since it is difficult to understand the fracture geometry on a regional scale and consider the same in GIS techniques. 
Table 4 Features of high, moderate and low groundwater potential zones

\begin{tabular}{|c|c|c|c|}
\hline Feature & High & Moderate & Low \\
\hline Slope & $0^{\circ}-5^{\circ}$ & $0^{\circ}-20^{\circ}$ & $5^{\circ}-20^{\circ} />20^{\circ}$ \\
\hline Land use & Agriculture, water body & Built-up, wasteland, forest & Built-up, wasteland, forest \\
\hline Geomorphology & Pediplain, water body, valley & Pediments & $\begin{array}{l}\text { Denudational hill, linear ridge, residual hill, } \\
\text { structural hill }\end{array}$ \\
\hline Geology & $\begin{array}{l}\text { Grey biotite gneiss, grey } \\
\text { biotite granite }\end{array}$ & $\begin{array}{l}\text { Grey biotite granite, meta-rhyolite, meta-basalt, } \\
\text { migmatite granite }\end{array}$ & Migmatite granite, dolerite dyke, quartzite \\
\hline $\begin{array}{r}\text { Drainage } \\
\text { density }\end{array}$ & $0-2.39 \mathrm{~km}^{-1}$ & $0-2.39 \mathrm{~km}^{-1}$ & $2.39-5.08 \mathrm{~km}^{-1}$ \\
\hline $\begin{array}{l}\text { Lineament } \\
\text { density }\end{array}$ & $0-0.39 / 0.39-1.08 \mathrm{~km}^{-1}$ & $0.39-1.08 / 1.08-2.96 \mathrm{~km}^{-1}$ & $1.08-2.96 \mathrm{~km}^{-1}$ \\
\hline
\end{tabular}

Well numbers

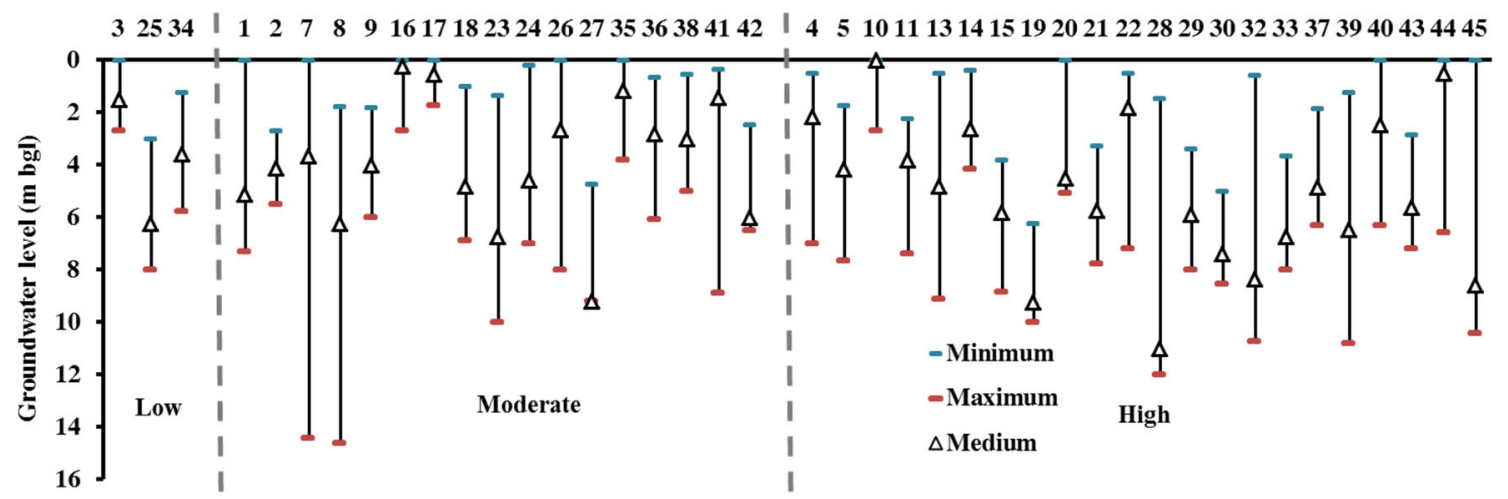

Fig. 10 Groundwater level fluctuations in different groundwater potential zones

\section{Conclusion}

Mapping and identifying the groundwater potential zones in an area help to plan for sustainable groundwater exploitation and management. As agriculture is the main activity in this part of Nalgonda district, India, the demand for groundwater resource is high. Conducive areas for groundwater occurrence and storage were identified based on slope, drainage density, land use, geology, lineament density and geomorphological features of this area. The best suitable areas identified were mainly in pediplain and valleys with minimum slope. Areas with agricultural practice provided wide possibility for groundwater development with high lineament density and low drainage density. Most of the area $\left(299.3 \mathrm{~km}^{2}\right)$ posed good groundwater recharge capacity. The areas identified based on integrated mapping of various features with intensive geological and geomorphological mapping were verified by field observation of groundwater level data which proved to be comparable. Favourable groundwater potential zones identified from this study will serve as a tool to various organisations and decision makers in planning for groundwater resource exploration and development in this area which will result in high yield.
Acknowledgments The authors acknowledge the Board of Research in Nuclear Sciences, Department of Atomic Energy, Government of India for funding this work (Grant No. 2007/36/35). Authors also thank the Department of Science and Technology's Funds for Improvement in Science and Technology scheme (Grant No. SR/FST/ESI-106/2010) and University Grants Commission's Special Assistance Programme [Grant No. UGC DRS II F.550/10/ DRS/2007(SAP-1)] for their support in creating laboratory facilities which helped in carrying out part of this work.

Open Access This article is distributed under the terms of the Creative Commons Attribution 4.0 International License (http:// creativecommons.org/licenses/by/4.0/), which permits unrestricted use, distribution, and reproduction in any medium, provided you give appropriate credit to the original author(s) and the source, provide a link to the Creative Commons license, and indicate if changes were made.

\section{References}

Ahmad Z, Ashraf A, Fryar A, Akhter G (2011) Composite use of numerical groundwater flow modeling and geoinformatics techniques for monitoring Indus Basin aquifer, Pakistan. Environ Monit Assess 173(1-4):447-457

Anbazhagan S, Jothibasu A (2014) Geoinformatics in groundwater potential mapping and sustainable development: a case study 
from southern India. Hydrol Sci J. doi:10.1080/02626667.2014. 990966

Bagyaraj M, Ramkumar T, Venkatramanan S, Gurugnanam B (2013) Application of remote sensing and GIS analysis for identifying groundwater potential zone in parts of Kodaikanal Taluk, South India. Front Earth Sci 7(1):65-75

Brindha K, Elango L (2010) Study on bromide in groundwater in parts of Nalgonda district, Andhra Pradesh. Earth Sci India 3(1):73-80

Brindha K, Elango L (2012) Groundwater quality zonation in a shallow weathered rock aquifer using GIS. Geo Spat Inf Sci 15(2):95-104

Brindha K, Elango L (2013a) Causes for variation in bromide concentration in groundwater of a granitic aquifer. Int $\mathrm{J}$ Res Chem Environ 3(2):163-171

Brindha K, Elango L (2013b) Occurrence of uranium in groundwater of a shallow granitic aquifer and its suitability for domestic use in southern India. J Radioanal Nucl Chem 295(1):357-367

Brindha K, Elango L, Nair RN (2011) Spatial and temporal variation of uranium in a shallow weathered rock aquifer in southern India. J Earth Syst Sci 120(5):911-920

Burrough PA (1986) Principles of geographical information systems for land resources assessment. Oxford University Press, Oxford, p 193

CGWB (Central Ground Water Board) (2007) Ground water information Nalgonda district Andhra Pradesh, India

Chenini I, Mammou AB (2010) Groundwater recharge study in arid region: an approach using GIS techniques and numerical modeling. Comput Geosci 36(6):801-817

Chipman JW, Lillesand TM (2007) Satellite-based assessment of the dynamics of new lakes in southern Egypt. Int J Remote Sens 28(19):4365-4379

Dar MA, Sankar K, Dar IA (2010) Groundwater prospects evaluationbased on hydrogeomorphological mapping: a case study in Kancheepuram district, Tamil Nadu. J Indian Soc Remote Sens 38(2):333-343

Dar IA, Sankar K, Dar MA (2011) Deciphering groundwater potential zones in hard rock terrain using geospatial technology. Environ Monit Assess 173(1-4):597-610

Elango L, Brindha K, Kalpana L, Sunny F, Nair RN, Murugan R (2012) Groundwater flow and radionuclide decay-chain transport modelling around a proposed uranium tailings pond in India. Hydrogeol J 20(4):797-812

Gaur S, Chahar BR, Graillot D (2011) Combined use of groundwater modeling and potential zone analysis for management of groundwater. Int J Appl Earth Obs Geoinf 13(1):127-139

GSI (Geological Survey of India) (1995) Geology and minerals map of Nalgonda district. Andhra Pradesh, India

Jasmin I, Mallikarjuna P (2011) Review: satellite-based remote sensing and geographic information systems and their application in the assessment of groundwater potential, with particular reference to India. Hydrogeol J 19(4):729-740

Javed A, Wani MH (2009) Delineation of groundwater potential zones in Kakund watershed, eastern Rajasthan, using remote sensing and GIS techniques. J Geol Soc India 73(2):229-236

Jha MK, Chowdary VM, Chowdhury A (2010) Groundwater assessment in Salboni Block, West Bengal (India) using remote sensing, geographical information system and multi-criteria decision analysis techniques. Hydrogeol J 18(7):1713-1728

Karunanidhi D, Vennila G, Suresh M, Karthikeyan P (2013) Geoelectrical Schlumberger investigation for characterizing the hydrogeological conditions using GIS in Omalur Taluk, Salem District, Tamil Nadu, India. Arab J Geosci 7:1791-1798

Kumar MG, Agarwal AK, Bali R (2008) Delineation of potential sites for water harvesting structures using remote sensing and GIS. J Indian Soc Remote Sens 36(4):323-334
Lillesand T, Kiefer RW, Chipman J (2007) Remote sensing and image interpretation. Wiley, Hoboken

Lone MS, Nagaraju D, Mahadavesamy G, Siddalingamurthy S (2013) Applications of GIS and remote sensing to delineate artificial recharge zones (DARZ) of groundwater in H.D. Kote taluk, Mysore district, Karnataka, India. Int J Remote Sens Geosci 2(3):92-97

Machiwal D, JhaM K, Mal BC (2011) Assessment of groundwater potential in a semi-arid region of India using remote sensing, GIS and MCDM techniques. Water Resour Manage 25(5):1359-1386

Madrucci V, Taioli F, deAraújo CC (2008) Groundwater favorability map using GIS multicriteria data analysis on crystalline terrain, São Paulo State, Brazil. J Hydrol 357(3-4):153-173

Magesh NS, Chandrasekar N, Soundranayagam JP (2012) Delineation of groundwater potential zones in Theni district, Tamil Nadu, using remote sensing, GIS and MIF techniques. Geosci Front 3(2):189-196

Manap MA, Nampak H, Pradhan B, Lee S, Sulaiman WNA, Ramli MF (2012) Application of probabilistic-based frequency ratio model in groundwater potential mapping using remote sensing data and GIS. Arab J Geosci. doi:10.1007/s12517-012-0795-Z

Manap MA, Sulaiman WNA, Ramli MF, Pradhan B, Surip N (2013) A knowledge-driven GIS modeling technique for groundwater potential mapping at the Upper Langat Basin, Malaysia. Arab J Geosci 6(5):1621-1637

Mondal MdS, Pandey AC, Garg RD (2008) Groundwater prospects evaluation based on hydrogeomorphological mapping using high resolution satellite images: a case study in Uttarakhand. J Indian Soc Remote Sens 36(1):69-76

Nagaraju D, Papanna C, Siddalingamurthy S, Mahadevaswamy G, Nagesha PC, Rao K (2011) Identification of groundwater potential zones through remote sensing and GIS techniques in Kollegal Taluk, Chamarajnagar District, Karnataka, India. Int J Earth Sci Eng 4(4):651-658

Narendra K, Rao KN, Latha PS (2013) Integrating remote sensing and GIS for identification of groundwater prospective zones in the Narava Basin, Visakhapatnam Region, Andhra Pradesh. J Geol Soc India 81(2):248-260

Ndatuwong LG, Yadav GS (2014) Integration of hydrogeological factors for identification of groundwater potential zones using remote sensing and GIS techniques. J Geosci Geomat 2(1):11-16

Ozdemir A (2011) Using a binary logistic regression method and GIS for evaluating and mapping the groundwater spring potential in the Sultan Mountains (Aksehir, Turkey). J Hydrol 405(1-2):123-136

Pandian M, Kumanan CJ (2013) Geomatics approach to demarcate groundwater potential zones using remote sensing and GIS techniques in part of Trichy and Karur district, Tamilnadu, India. Arch Appl Sci Res 5(2):234-240

Pareta K, Pareta U (2011) Hydromorphogeological study of Karawan watershed using GIS and remote sensing techniques. Int Sci Res J 3(4):243-268

Pinder GF (2002) Groundwater modelling using geographical information systems. Wiley, New York, p 248

Pinto D, Shrestha S, Babel MS, Ninsawat S (2015) Delineation of groundwater potential zones in the Comoro watershed, Timor Leste using GIS, remote sensing and analytic hierarchy process (AHP) technique. Appl Water. doi:10.1007/s13201-015-0270-6

Prasad RK, Mondal NC, Banerjee P, Nandakumar MV, Singh VS (2008) Deciphering potential groundwater zone in hard rock through the application of GIS. Environ Geol 55(3):467-475

Preeja KR, Joseph S, Thomas J, Vijith H (2011) Identification of groundwater potential zones of a tropical river basin (Kerala, India) using remote sensing and GIS techniques. J Indian Soc Remote Sens 39(1):83-94 
Rai B, Tiwari A, Dubey VS (2005) Identification of groundwater prospective zones by using remote sensing and geoelectrical methods in Jharia and Raniganj coalfields, Dhanbad district, Jharkhand state. J Earth Syst Sci 114(5):515-522

Rajaveni SP, Brindha K, Rajesh R, Elango L (2014) Spatial and temporal variation of groundwater level and its relation to drainage and intrusive rocks in a part of Nalgonda District, Andhra Pradesh, India. J Indian Soc Remote Sens 42(4):765-776

Rajesh R, Brindha K, Murugan R, Elango L (2012) Influence of hydrogeochemical processes on temporal changes in groundwater quality in a part of Nalgonda district, Andhra Pradesh, India. Environ Earth Sci 65:1203-1213

Ramaiah SN, Gopalakrishna GS, Vittala SS, Najeeb KMd (2012) Geomorphological mapping for identification of ground water potential zones in hard rock areas using geo-spatial information-a case study in Malur Taluk, Kolar District, Karnataka, India. Nat Environ Pollut Technol 11(3):369-376

Rao NS (2006) Groundwater potential index in a crystalline terrain using remote sensing data. Environ Geol 50(7):1067-1076

Rashid M, Lone MA, Ahmed S (2012) Integrating geospatial and ground geophysical information as guidelines for groundwater potential zones in hard rock terrains of south India. Environ Monit Assess 184(8):4829-4839

Sener E, Davraz A, Ozcelik M (2005) An integration of GIS and remote sensing in groundwater investigations: a case study in Burdur, Turkey. Hydrogeol J 13(5-6):826-834

Srinivasan K, Poongothai S, Chidambaram S (2013) Identification of groundwater potential zone by using GIS and electrical resistivity techniques in and around the Wellington reservoir, Cuddalore district, Tamilnadu, India. Eur Sci J 9(17):312-331

Suganthi S, Elango L, Subramanian SK (2013) Groundwater potential zonation by remote sensing and GIS techniques and its relation to the groundwater level in the coastal part of the Arani and Koratalai River Basin, Southern India. Earth Sci Res J 17(2):87-95

Varughese A, Suhail A, Chitra MG, Jiji PS, Deepthy C, Raneesh KY (2012) Identification of shallow groundwater potential zones using GIS - a case study. Int J Adv Eng Appl 1(4):65-70

Vittala SS, Govindaiah S, Gowda HH (2005) Evaluation of groundwater potential zones in the sub-watersheds of North Pennar river basin around Pavagada, Karnataka, India using remote sensing and GIS techniques. J Indian Soc Remote Sens 33(4): $483-493$ 